\title{
Belenggu Patriarki pada Peran Laki-Laki Bangsawan Jawa dalam Film Kartini Karya Hanung Bramantyo
}

\author{
Ulmi Marsya, Johan Faladhin \\ Program Studi Hubungan Masyarakat, Fakultas Ilmu Komunikasi \\ Universitas Muhammadiyah Riau \\ ulmimarsya@umri.ac.id
}

\begin{abstract}
The struggle of Raden Ayu Kartini to gain freedom for Javanese women who were hindered by the great walls of culture and tradition, often associated with patriarchal culture which was said to give more privileges to men than women. But in fact the privileges possessed by men instead of giving freedom, it also binds his mind to the true roles and behavior of men who have been established in the patriarchal culture itself.
\end{abstract}

Keywords: Film, Patriarchal Culture, Kartini, Men

\section{Pendahuluan}

Kartini dikenal sebagai seorang tokoh emansipasi wanita yang memperjuangkan kebebasan perempuan khususnya perempuan Jawa dari budaya dan tradisi yang memenjarakan tubuh serta pikiran kaum perempuan pada masanya. Peran seorang Kartini dinilai begitu besar pada terbukanya akses pendidikan bagi kaum perempuan Indonesia sehingga kini kita mengenalnya sebagai salah seorang pahlawan nasional Indonesia, dan tanggal 21 April yang merupakan hari kelahirannya diperingati setiap tahunnya sebagai hari Kartini.
Kartini merupakan putri dari Bupati Jepara bernama Raden Mas Adipati Ario Sosroningrat, yang berarti bisa dikatakan Kartini berasal dari keluarga ningrat, namun ia sangat bersimpati kepada rakyat jelata dan penderitaan mereka. Seperti yang tertulis dalam suratnya kepada Estelle Zeehandelar yang dikutip oleh Pramoediya Ananta Toer dalam buku biografinya "Panggil Aku Kartini Saja” (2015),

"Disebut bersama dengan Rakyatku; dengannyalah dia akan berada buat selamalamanya! Aku sangat bangga, Stella, disebut dengan satu napas dengan Rakyatku" melalui potongan surat ini, Toer melihat bagaimana seorang Kartini meskipun ia tidak memiliki 
kesempatan yang banyak untuk lebih mengenal rakyatnya karena kedudukan ningratnya, namun itu saja sudah cukup banyak baginya untuk dijadikan sebagai modal mencintai, menghargai, dan menderita untuk rakyatnya. Meskipun ia sendiri juga menderita karena terkungkung oleh adat kebiasaan. Toer menyebut Kartini sebagai pemula dari sejarah modern Indonesia yang meramu segala aspirasi kemajuan Indonesia yang dimulai pertama kali di Demak, Kudus, Jepara sejak pertengahan kedua abad ke 19.Jasa besar Kartini terutama bagi perempuan Indonesia, menjadikan kisahnya layak untuk diangkat menjadi sebuah film sebagai media pembelajaran bagi masyarakat untuk lebih mengenal Pahlawan Bangsanya.

Bertolak dari situ, Hanung Bramantyo mengangkat kembali kisah Kartini dalam sebuah film pada tahun 2017, yang mana sebelumnya kisah Kartini juga pernah diangkat menjadi sebuah film dengan judul R.A Kartini (1984) dan Surat Cinta untuk Kartini (2016). Seperti halnya film terdahulu, Film ini mengisahkan perjuangan seorang Raden Ayu Kartini dalam mendapat akses pendidikan modern yang ia percaya dapat membebaskan dirinya dari belenggu kebudayaan bangsawan Jawa yang rumit dan menyakitkan. Pada film ini tentu memfokuskan pada karakter Kartini sebagai tokoh sentral serta problematika yang menyelimuti kehidupannya sebagai Raden Ayu (Anak perempuan bangsawan Jawa).Dalam film ini juga Hanung mencoba untuk menampilkan praktik-pratik budaya Jawa yang dikhususkan pada kaum perempuan berdarah ningrat untuk kemudian dijadikan sebagai Raden Ayu.Namun dalam memberikan gambaran tradisi-tradisi budaya Jawa yang membelit kehidupan Kartini dan dua orang adik perempuannya, juga tidak lepas dari gambaran peran laki-laki disekitarnya yang harus menjalani kehidupan sebagai lakilaki bangsawan.Terlebih menurut pengakuan Hanung sendiri dalam wawancara dengan CNN Indonesia, bahwa ia ingin menampilkan khususnya pada laki-laki untuk dapat mendalami sosok kartini dan melihat perjuangannya. ${ }^{1}$

Meskipun yang menjadi pokok utama dalam cerita adalah perjuangan akan kebebasan kaum perempuan khususnya Kartini dan adikadik perempuannya dari belenggu tradisi kebudayaan yang lebih banyak memberikan keistimewaan bagi kaum laki-laki. Hanung juga berusaha untuk menampilkan bentuk dominasi kaum laki-laki sedang kaum perempuan menempati posisi marjinal.Seorang laki-laki bangsawan dianggap lebih memiliki wewenang dalam hidupnya seperti dapat memiliki istri lebih dari satu, sebagai pengambil keputusan, serta juga yang memiliki wewenang untuk mengatur kehidupan keluarganya sebagaimana budaya yang dianutnya.Sedang perempuan mau tidak mau harus rela meneriman segala

\footnotetext{
${ }^{1}$ Agnia Khoiri, "Jatuh Bangun Hanung Bramantyo, Hidupkan Perjuangan Kartini", diakses pada 13 January 2019, https://www.cnnindonesia.com/hiburan/201703212 00126-220-201824/jatuh-bangun-hanungbramantyo-hidupkan-perjuangan-kartini
} 
keputusan ayah, kakak laki-laki, suami, dan lainnya.

Namun dalam hak keistimewaan yang didapatkan kaum laki-laki priayi akibat budaya patriarki yang sangat kental pada masyarakat Jawa tersebut, juga terdapat masalah pada konsep kebebasan yang diusung dalam cerita ini yang dikatakan hanya milik kaum lakilaki.Meskipun laki-laki digambarkan bebas mendapatkan akses pendidikan modern serta berhak menentukan nasib keluarganya, ternyata hak-hak laki-lakitersebut tidak dapat terlepas dari belenggu budaya yang membelit kehidupan. Secara implisit, laki-laki juga tidak memiliki kuasa atas keputusan-keputusan yang diambilnya. Ketika ia dihadapkan pada sebuah pengambilan keputusan untuk kepentingan keluarganya, seorang laki-laki bangsawanpun terpaksa harus melawan nuraninya sendiri demi tuntutan peran yang disandangnya sebagai lakilaki bangsawan Jawa. Makadari itu, artikel ini ingin mengupas bagaimana film Kartini karya Hanung Bramantyo ini membarikan gambaran mengenai peran laki-laki priyayi Jawa yang terlenggu antara nuraninya sebagai seorang Ayah atau kakak laki-laki dengan adat istiadat Jawa yang dianutnya. Ditambah lagi, ada beberapa jalan cerita yang dituliskan oleh Hanung Bramantyo pada film tersebut tenyata berbeda dengan literatur sejarah Kartini yang berkaitan dengan Ayah dan silsilah keluarga Kartini.

\section{Peran Gender dalam Media (Film)}

Konsep gender yang dalam hal ini menjelaskan mengenai kategorisasi laki-laki dan perempuan yang dibangun secara sosial dan budaya. Pemahaman mengenai perbedaan peran laki-laki dan perempuan pun merupakan suatu konstruksi sosial yang lahir dari ideologi gender itu sendiri. Selain itu, akar pikiran yang ditawarkan merupakan hasil konstruksi sosial, budaya, agama, dan ideologi tertentu yang mengenal batas ruang dan waktu sehingga bersandingan pada nilai-nilai masyarakat dan berubah menurut situasi dan kondisi.Film hadir sebagai bagian media massa yang dapat menjadi cerminan dari isu yang terjadi dalam masyarakat, karena menampilkan realitas permasalahan manusia, baik faktual maupun fiksional. Penampilan wacana ketidakadilan gender salah satunya, ini seolah dapat diterima sebagai suatu hal yang wajar. Disebabkan pelaku media selalu menghantarkan informasi tanpa disertai upaya untuk menempatkan suatu wacana dalam suatu cara pandang yang menekankan bahwa perilaku seseorang dapat dimengerti dengan sangat baik jika diketahui peranan sosialnya.

Menurut Hermes dalam McQuail (2012 : 131) berpendapat bahwa kita perlu memahami bagaimana media menampilkan gender karena konstruksi feminitas dan maskulinitas merupakan bagian dari ideologi dominan. Selain hal ini, ia juga menunjukkan bahwa media masih menawarkan contoh dan panduan perilaku 
umum dan kita harus dapat menafsirkan pesanpesan ini. Media sesungguhnya berada di tengah realitas sosial yang sarat dengan berbagai kepentingan, konflik, dan fakta yang komplek dan beragam. Louis Althusser (1971, dalam Zastrouw, 2000) menulis bahwa media, dalam hubungannya dengan kekuasaan, menempati posisi trategis, terutama Karena anggapan akan kemampuannya sebagai sarana legitimasi. Media massa sebagaimana lembaga Pendidikan, agama, seni, dan kebudayaan, merupakan bagian dari alat kekuasaan negara yang bekerjasama secara ideologis guna membangun kepatuhan khalayak terhadap kelompok yang berkuasa (ideological states apparatus) (Sobur 2009 : 29 - 30). Peran laki-laki di media massa sering digambarkan dengan peran yang khas. Dalam media massa Indonesia peran laki-laki sering digambarkan sebagai seorang yang berwibawa, pekerja keras, betanggung jawab dan menjadi pahlawan bagi orang lain. Media telah memberikan gambaran pada masyarakat tentang bagaimana seharusnya menjadi seorang laki-laki. Mayoritas media massa (termasuk film) masih menampilkan konten tentang konstruksi nilai dan peran yang bias gender (Dayanti, 2011).

\section{Stereotype ataupun branding yang} diberikan masyarakat pada sosok laki-laki tidak terlepas dipengaruhi oleh budaya yang ada.Berbagai macam budaya yang melekat dimasyarakat, membuat perbedaan dalam menentukan sifat khas laki-laki yang seolah harus dimilki (Syulhajji, 2017).Pada kebanyakan budaya masyarakat Indonesia, sosok laki-laki erat dengan sifat dan karakter yang menonjol atau unggul baik dalam keluarga, pekerjaan, pengambilan keputusan dan pemecahan permasalahan.Budaya yang dipahami masyarakat tentang sifat dan karakter laki-laki seolah menjadi acuan bagaimana seharusnya menjadi seorang laki-laki. Melalui bermacam media, baik disampaikan secara tradisional sampai modern, aturan dan simbol budaya sifat khas laki-laki dapat diterima oleh masyarakat (Dermatoto, 2010). Film Kartini karya Hanung Bramantyo menawarkan nilai yang berbeda. Film ini justru hadir untuk memberikan kritik terhadap budaya patriarki yang kental pada kebudayaan leluhur Indonesia.Penyelarasan budaya partriatkhi dalam film Kartini yang di kemas sesuai dengan plot, kemudian menjadi hal yang menarik. Bukan hanya membelenggu perempuan, namun juga penggambaran ketidakberdayaan sosok peran laki-laki seorang ayah maupun saudara laki-laki yang dikaitkan dengan pengaruh unsur budaya Jawa, sangat kental.Kepemimpinan seorang laki-laki dapat dikatakan baik, apabila tepat dalam pengambilan keputusan maupun pemecahan sebuah permasalahan.Sehingga, hal ini tidak berbanding lurus dengan isu gender dalam film ini karena pengambilan keputusan sesungguhnya bukan berada ditangan laki-laki, namun sistem budaya dan juga pemerintahan kolonial pada masa itu.

Antara Keistmewaan dan Belenggu Laki-laki dalam Budaya Patriarki

Budaya patriarki, sejatinya sering kali dinilai sebagai budaya yang memberikan hak 
keistimewaan bagi salah satu jenis kelamin yaitu laki-laki atau disebut juga kuasa patriarkhal yang terjadi dalam relasi antara laki-laki dan perempuan.Dalam konsep Hegemoni yang dicetuskan oleh Gramschi, patriarki yang tampak dalam segala macam simbol maskulinitas, direproduksi secara terus menerus dan diwariskan oleh lembaga-lembaga sosial dan budaya (Rahayu, 2012:66), termasuk juga bentuk hirarki dalam dalam jenis kelamin.Dalam teori Hegemoni maskulin olehConnell (2005), menyebutkan bahwa Hegemoni maskulin merujuk pada bentuk atau praktik gender yang mendukung kelangsungan budaya patriarki dengan memberi hak-hak keistimewaan bagi laki-laki untuk mendominasi dan mengsubordinasikan posisi perempuan.Bukan hanya bagi perempuan, tapi hegemoni maskulin juga memarjinalkan posisi laki-laki dari kelompok tertentu.Dalam artian yang tidak sesuai dengan konsep maskulin yang dominan, dan tidak semua manusia berjenis kelamin lakilaki yang mendapatkan label maskulin. Dalam tataran ini, manusia yang berjenis kelamin lakilaki namun tidak maskulin, sama halnya dengan kelompok marjinal lain seperti perempuan. Beauvoir (2016) menegaskan bahwa dengan ditegakkannya hirarki dalam jenis kelamin, keduanya pun, baik dari pihak yang berkuasa dan dikuasai maka pihak yang diistimewakan ini akan berusaha tetap mempertahankan posisinya dan menguasai pihak yang lain. Hak keistimewaan laki-laki yang diciptakan budaya patriarki kemudian diwariskan dan menjadi konsep diri atau prinsip hidup sebagai seorang laki-laki.Kecenderungan untuk mempertahankan kuasanya serta prinsipnya sebagai seorang lakilaki, sehingga menjadikan laki-laki tidak lagi melihat dirinya sebagai manusia melainkan sebagai diri laki-laki.Penganut paham strukturalisme beranggapan bahwa bukan diri yang membentuk budaya, akantetapi budaya yang membentuk diri (Arivia, 2003:64).Seperti halnya laki-laki yang dengan hak istimewa, dirinya sebagai seorang laki-laki dan berasal dari kaum bangsawan.

Peramasalahan hegemoni maskulin tidak dapat diabaikan begitu saja. Melihat ia dibentuk dari berbagai elemen sosial dalam masyarakat. Connell (2005) mengatakan bahwa secara empiris, hegemoni maskulin dapat dianalisis pada tiga level, yaitu lokal, regional, dan global. Pada level lokal, konstruksi hegemoni dibentuk dalam arena keluarga, organisasi, ataupun komunitas yang intim, seperti yang sering ditemukan pada riset etnografi atau tentang sejarah kehidupan. Selajutnya adalah level regional, konstruksi hegemonik terbetuk dalam level budaya atau Negara-bangsa, seperti yang sering terdapat pada riset diskursus, politik, dan demografi. Kemudian pada level yang lebih luas yaitu level global, konstruksi hegemonic dibentuk pada arena transnasional seperti media, politik dunia, dan lainnya seperti yang sering terdapat pada penelitian tentang maskulinitas dan globalisasi. 
Dalam kebudayaan Jawa misalnya yang dijelaskan oleh Suryadi dalam Triatnawati (2005:301), bahwa kesuksesan laki-laki diukur melalui lima hal, yaitu: wisma, turangga, curiga, kukila, dan wanita. Kelima hal ini menjadi penanda dari kejantanan laki-laki.Dalam konteks kisah Kartini sendiri, ia merupakan putri bangsawan Jawa, ayahnya adalah seorang Bupati Jepara pada masa kolonial bernama R.M.

Adipati Ario Sosroningrat. Dalam silsilah keluarga, Kartini merupakan putri ke lima R.M. Adipati Ario Sosroningrat dari istri keduanya yang bernama Ngasirah. Ibu Kandung Kartini sendiri bukan merupakan keturunan bangsawan Jawa.Namun menurut Toer (2015) belum ada sejarah yang mengungkap dengan lugas mengenai ibu kandung Kartini.Hal ini sangat mungkin terjadi karena status ibu kandung Kartini bukan merupakan darah bangsawan Jawa.Karena pada masa kolonialisme Belanda, dalam sistem feodalisme pribumi cenderung enggan untuk mengungkapkan keberadaan seorang wanita yang berasal dari kaum jelata (bukan bangsawan) masuk kedalam keluarga bangsawan untuk mendampingi seorang Bupati.Stigma yang beredar biasanya satusatunya hal yang dapat membuat seorang wanita jelata bisa menjadi istri seorang bangsawan hanya sebatas karena wajahnya yang cantik atau kemolekan tubuhnya.

Kartini sendiri, yang dianggap sebagai wanita yang memiliki keberanian untuk berbicara jujur, tiada pernah berbicara mengenai ibu kandungnya (Toer, 2015). Hal ini menjadi sebuah tanda Tanya besar, apa gerangan yang membuat Kartini tidak pernah berbicara mengenai ibu kandungnya. Kuat dugaan bahwa alasan Kartini sesungguhnya karena ia tidak ingin menyakiti ayahnya atau melindungi ayahnya. Besarnya cinta Kartini kepada ayahnya tergambar dalam surat yang ditulisnya untuk Estella Zeehandeelar dalam Toer (2015:56-57), yaitu:

"Kasihan ayahku tercinta, ia telah begitu banyak menanggung, dan hidup ini masih jua timpakan kekecewaan-kekecewaan menyedihkan pula kepadanya. Stella, ayah tiada mempunyai sesuatu terkecuali anakanaknya, kami inilah segala-galanya baginya, kegembiraannya, penghiburku.Aku mencintai kebebasanku, o, dialah segala-galanya yang kumiliki, dan nasib saudarisaudariku sangat meminta perhatianku; aku rela membantu mereka kuat-kuat, dan siap sedia menyerahkan apapun korban yang dipintanya, agar dapat memperbaiki nasib mereka.Aku pandang menjadi kebahagiaan hidup, bila dapat dan boleh menyerahkan diri seluruhnnya buat pekerjaan ini.Namun lebih baik daripada semua itu seluruhnya adalah ayahku. Stella, katakanlah aku pengecut, goyah, tapi aku tidak dapat berbuat lain; kalau ayah melarang aku berusaha buat itu, betapapun meraung dan merintih 
hatiku, aku akan terima larangan itu dengan tawakal. Keberanianku tidaklah cukup, untuk makin melukai, dan makin mendarahkan hatinya, hati yang setia itu, yang begitu menyayangi daku."

Dalam surat ini, tersirat bagaimana Kartini tidak ingin bahkan sangat takut akan melukai perasaan ayahnya yang dia sebut sudah sangat banyak menanggung penderitaan. Kenyataan ini pula yang membuatnya tidak dapat menyebut ibunya yang merupakan seorang wanita dari rakyat jelata yang menjadi istri kedua ayahnya, karena akan membuat nama ayahnya sebagai seorang bangsawan dan bupati Jepara menjadi tercoreng. Kedudukan ayahnya yang memiliki darah keturunan bangsawan dari Raja Jawa, disatu sisi memberikan keistimewaan dalam bentuk kekuasaan atas rakyat dan keluarganya, namun disisi lain kekuasaan itu sesungguhnya bukan milik dirinya secara pribadi. Laki-laki sebagai manusia, tidak serta merta punya pilihan sendiri, melainkan tuntutan ada istiadat dan juga penguasa kolonial.Seperti halnya yang diungkapkan oleh Kartini kepada Stella, meskipun ayahnya memiliki kedudukan dan pengaruh yang besar dalam masyarakat, tapi tidak dengan kekuasaan. Yang memiliki kekuasaan hanyalah para penguasa kolonial, sedang ayahnya sama layaknya pribumi lainnya, namun hanya diuntungkan karena memiliki darah bangsawan dan kedudukan yang tinggi (Toer, 2015: 65).

\section{Metode penelitian}

Pada kajian ini menggunakan metode penelitian deskriptif kualitatif mengenai, bagaimana film yang mengangkat tema sejarah, pada penulisan ini mengenai perjuangan seorang Raden Ayu Kartini mendapatkan kebebasan dan akses pendidikan bagi kaum jelata dan perempuan. Fokus dalam penelitian ini adalah menjabarkan bahwa film garapan Hanung Bramantyo ini, disamping untuk menyajikan sejarah, namun juga dalam perspetif industry juga menampilkan hal-hal yang sifatnya dramatic namun sedikit merubah fakta-fakta sejarah yang terdapat dalam literature sejarah R.A Kartini, terutama dalam isu bagaimana kebebasan digambarkan hanya milik kaum lakilaki, namun ternyata tidak sepenuhnya. Karena gelar kebangsawanan seorang laki-laki justru mengungkungnya kedalam tradisi dan kuasa kolonialisme.

Pembahasan

Kebebasan, merupakan hal yang sangat dirindukan oleh seorang putri dari Bupati Jepara R.M. Ario Sosroningrat, yang bernama Raden Ajeng Kartini. Film garapan Hanung Bramantyo yang tayang pada tahun 2017 ini, mengangkat kembali tema perjuangan Kartini dengan menggandeng beberapa artis besar kenamaan seperti Dian Sastro Wardoyo, Christine Hakim, Reza Rahardian, Djenar Maesa Ayu, dan lainlain. Seperti yang telah disinggung diatas, Hanung memberikan penekanan khususnya pada laki-laki untuk dapat memahami Kartini dan 
perjuangannya untuk mendapatkan kebebasan sebagai perempuan bangsawan yang diharuskan menjadi seorang Raden Ayu. Karena dengan tradisi tersebut dalam sistem feodalisme yang mereka anut, mengharuskan anak perempuan berdarah bangsawan untuk mempersiapkan diri menjadi seorang Raden Ayu dengan manjalani berbagai tradisi seperti pingitan yang mana seorang anak perempuan setelah mendapat menstruasi pertamanya harus dipingit sembari belajar bagaimana caranya menjadi Raden Ayu hingga tiba saatnya dia dipinang oleh seorang pria bangsawan tidak peduli pria tersebut sudah memiliki istri atau belum. Namun disisi lain, laki-laki pun dalam gambaran ini tidak sepenuhnya mendapatkan kebebasan, terutama dengan status kebangsawanan yang mereka sandang. Peran laki-laki yang ditampilkan oleh Hanung adalah, pertama Ayah Kartini, R.M Adipati Ario Sosroningrat.Kedua Kakak lakilaki Pertama Kartini bernama R.M Slamet Sosroningrat, Kakak laki-laki kedua Kartini bernama P.A Sosrobusono dan kakak laki-laki ketiga Kartini bernama R.M Sosrokartono.

Dari keempat laki-laki yang ditampilkan dalam film ini, hanya satu yang digambarkan mampu keluar dari tradisi adat yang dalam sistem feodalisme yang mereka anut. Yaitu R.M. Sosrokartono yang akan berangkat untuk menimba ilmu di negeri Belanda. Peran Sosrokartono yang dibawakan oleh Reza Rahadian ini merupakan salah satu tokoh penting meski muncul hanya sebentar pada awal cerita.R.M Sosrokartono lah yang pertama kali membuka jalan bagi Kartini untuk membuka pikiran lebih jauh meskipun tubuh terkurung dibalik tembok-tembok istana.R.M Sosrokartono berkata kepada Kartini bahwa "Jangan biarkan pikiranmu terpenjara Kartini, aku tunggu di Belanda". Pada adegan ini, Kakak laki-laki Kartini, sebelum berangkat menuntut ilmu ke Negeri Belanda, berpesan kepada Kartini adik perempuannya yang sedang dalam masa pingitan untuk dapat membebaskan pikirannya walaupun sedang terkurung oleh "tembok-tembok tradisi". Lalu ia menghadiahi Kartini kunci kamarnya yang terdapat banyak buku-buku yang berbahasa Belanda yang kemudian membuat Kartini dapat membuka luas wawasan dan pikirannya untuk menjadi seorang perempuan yang bebas menentukan hidupnya. R.M Sosrokartono digambarkan sebagai laki-laki yang terpelajar karena dia memiliki banyak buku-buku yang berasal dari Belanda dan pada saat itu akan segera melanjutkan pendidikannya ke Negara Belanda. Dalam konteks ini, menimbulkan kesan bahwa R.M Sosrokartono merupaka laki-laki bangsawan pribumi yang telah tercerahkan pikirannya karena ia adalah seorang laki-laki yang terpelajar.

Tiga laki-laki bangsawan pribumi yang lain ialah Ayah Kartini, R.M. Adipati Ario Sosroningrat dan kedua kakak laki-laki nya R.M Slamet Sosroningrat dan P.A Sosrobusono ditampilkan sebagai laki-laki bangsawan yang masih memegang teguh adat dan tradisinya. R.M.Adipati Ario Sosroningrat digambarkan sebagai seorang laki-laki pemimpin karena ia 
merupakan seorang bangsawan yang memegang jabatan sebagai Bupati Jepara. Menurut Suwarno dalam Hasan (2012), ketika masa feodalisme pemerintah pusat yaitu kerajaan dengan pemerintah daerah tersentralisasi.Raja mengangkat para keluarga atau kerabat kerajaan untuk memegang posisi-posisi penting dalam pemerintahan daerah seperti Bupati.Raja memilih orang-orang yang dapat dipercaya dan tidak mengkhiati kerajaan.Pada zaman kerajaan, bupati memiliki wewenang yang otonom dalam menjalankan pemerintahan tanpa pengawasan ketat dari Raja.Wedana hanya mangawasi loyalitas Bupati pada kerajaan.Namun pada pemerintahan Kolonial, para Bupati yang berasal dari bangsawan pribumi harus berperan sebagai agen pemenuhan ambisi pemerintahan colonial Belanda.Gambaran peran Bupati yang dijabat oleh ayah Kartini dalam film ini justru kebalikan.Orang-orang Belanda yang ditampilkan oleh Hanung, justru lebih cenderung mendukung agar R.M Adipati Ario Sosroningrat untuk mengizinkan anak-anak perempuannya menggapai impian mereka.

\section{Kuasa yang Membelenggu Laki-laki Bangsawan}

Beberapa bagian (scene) yg menggambarkan adanya belenggu patriarki pada kaum laki-laki di atas akan disajikan dalam tabel berikut: 


\section{Tabel 1}

\section{Scene Belenggu Patriarki pada Kaum Laki-Laki}

\begin{tabular}{|c|c|c|}
\hline Laki-laki bangsawan & Budaya dan peran laki-laki & Belenggu dominasi maskulin \\
\hline R.M. Adipati Ario Sosroningrat & $\begin{array}{l}\text { Laki-laki, bangsawan, Kepala } \\
\text { keluarga, Bupati. }\end{array}$ & $\begin{array}{l}\text { "Romo mengerti, tapi } \\
\text { perjodohanmu sudah ditentukan } \\
\text { sebelum kamu masuk pingitan. } \\
\text { Romo sudah terlanjur berjanji, } \\
\text { nak. Romo sebagai bangsawan } \\
\text { tidak bisa mencederai janji". } \\
\text { (Menunjukkan pertentangan } \\
\text { antara nurani sebagai bapak dan } \\
\text { sebagai laki-laki bansawan.) } \\
\text { R.M Adipati Ario Sosroningrat, } \\
\text { oleh karena desakan tradisinya } \\
\text { sebagai seorang bangsawan, } \\
\text { mengharuskan ia untuk } \\
\text { melakukan poligami yang tidak } \\
\text { ingin dia lakukan. } \\
\text { Sebagai ayah, R.M Adipati Ario } \\
\text { Sosroningrat memutuskan untuk } \\
\text { memberi izin pada Kartini untuk } \\
\text { belajar keluar negeri, tapi } \\
\text { keputusan tersebut ditentang oleh } \\
\text { bangsawan lain dengan dalih } \\
\text { mempertahankan tradisi. Hingga } \\
\text { ia jatuh sakit. }\end{array}$ \\
\hline $\begin{array}{l}\text { R.M Slamet Sosroningrat dan } \\
\text { P.A Sosrobusono. }\end{array}$ & $\begin{array}{l}\text { Laki-laki, bangsawan, anak tertua } \\
\text { dan kedua, calon pejabat. }\end{array}$ & $\begin{array}{l}\text { Menjauhi ibu kandungnya karena } \\
\text { ibunya seorang rakyat jelata. } \\
\text { Nasib jabatannya ditentukan oleh } \\
\text { pihak kolonial. }\end{array}$ \\
\hline
\end{tabular}


Pendidikan yang notabene merupakan dari barat, yang ditampilkan pada diri R.M Sosrokartono adalah hal yang memberinya pencerahan untuk dapat keluar dari tradisi-tradisi lama termasuk juga mengenai hak perempuan untuk mendapatkan pendidikan.Hal yang justru membelenggu R.M. Adipati Ario Sosroningrat adalah tradisi yang mereka anut. Misalnya pada adegan, anak perempuannya yang bernama R.A Kardinah, akan dipersunting oleh seorang bangsawan yang memiliki jabatan sebaga wakil bupati Pemalang. Kardinah menangis kepada Romonya (Ayah) agar tidak dinikahkan dengan laki-laki yang sudah memiliki istri, namun dengan berat hati ayahnya mengatakan "Romo mengerti, tapi perjodohanmu sudah ditentukan sebelum kamu masuk pingitan.Romo sudah terlanjur berjanji, nak.Romo sebagai bangsawan tidak bisa mencederai janji”. Adegan ini menampilkan beberapa scene yang menunjukkan kegundahan hati R.M Adipati Ario Sosroningrat ketika anak perempuanya akan dipinang oleh laki-laki yang sudah beristri. Namun dengan gelar bangsawan yang ia sandang, ia merasa terbelenggu untuk mengambil keputusan yang sesuai dengan nuraninya yang sangat mencintai anak perempuannya.

Menjadi laki-laki, dalam budaya yang menganut paham patriarki yang kental tidak dapat disebut sebagai kebebasan yang mutlak.Laki-laki juga sering harus melawan dirinya sendiri demi perannya sebagai laki-laki dan kepala keluarga, termasuk dalam pengambilan keputusan.Hal ini terrepresentasikan dalam adegan ketika ayah Kartini diminta oleh ayahnya untuk menikahi seorang wanita bangsawan keturunan Ratu Maduran bernama R.A Moeriyam Sosroningrat. Ayah Kartini menolak untuk menikah lagi karena takut akan menyakiti hati istrinya M.A Ngasirah. Tekad R.M Adipati Ario Sosroningrat akhirnya tergoyahkan karena desakan dari Ngasirah yang menyatakan ikhlas demi anakanaknya kelak mendapatkan pendidikan yang layak.Dalam adegan ini terlihat bagaimana keputusan sesungguhnya bukan berada di tangan R.M Adipati Ario Sosroningrat, melainkan dari desakan tradisinya sebagai seorang bangsawan. Terlebih juga ia tidak dapat memilih dan menderita karena peran yang dipangkunya. Seorang laki-laki dipaksa harus menjadi sosok yang paling kuat dan berpikir logis (demi kepentingan rakyat) dibandingkan dengan kepentingan kehidupan pribadinya.Hal ini terbukti juga seperti yang pernah diungkapkan oleh Kartini bahwa ayahnya meskipun memiliki pengaruh yang besar namun, tidak dengan kekuasaan.Dan ayahnya sudah banyak mengalami berbagai penderitaan.

Penggambaran praktik poligami yang dilakukan oleh ayah Kartini oleh Hanung Bramantyo sedikit berbeda dengan literatur sejarah Kartini.Karena dalam silsilah keluarga, sesungguhnya Ngasirah (ibu kandung Kartini) merupakan istri kedua R.M Sosroningrat dan yang menjadi istri pertama adalah R.A Moeriyam Sosroningrat.Ngasirah yang bukan 
merupakan keturunan bangsawan tapi bisa memiliki hubungan dengan seorang laki-laki bangsawan itu merupakan salah satu hal yang hampir tidak mungkin.Sehingga hubungan keduanya tidak banyak diekspos kepada publik.Toer (2015) juga memperkirakan bahwa Kartini tidak ingin terlalu banyak berbicara mengenai ibu kandungnya tersebut karena ingin melindungi ayahnya yang sudah banyak mengalami berbagai penderitaan. Penderitaan R.M Adipati Ario tidak hanya sampai disana, pada bagian klimaks cerita dimana para orang Belanda yang mengagumi Kartini merekomendasikan pada beasiswa untuk Kartini dapat menempuh pendidikan di Negeri Belanda. Sebagai ayah, R.M Adipati Ario Sosroningrat memutuskan untuk memberi izin pada Kartini, tapi keputusan tersebut ditentang dengan keras oleh berbagai pihak (para bangsawan lain), dengan dalih mempertahankan tradisi. Kondisi ini kemudian membuat Ayah Kartini jatuh sakit yang membuat dirinya tak lagi berdaya.

Bukan hanya R.M Adipati Ario Sosroningrat yang menunjukkan ketundukan laki-laki pada sistem pemerintahan dan budayanya.Kedua puteranya yang bernama R.M Slamet Sosroningrat dan P.A Sosrobusono juga mengalaminya. Berbeda dengan penggambaran R.M Sosrokartono yang terpelajar dan tercerahkan, kedua Kakak laki-laki Kartini yang lain tidak digambarkan sebagai kaum yang terpelajar, mereka justru sangat sinis terhadap pendidikan ala barat yang akan membuat adik perempuan mereka menjadi perempuan liar.
Sehingga beberapa kali berusaha menggagalkan usaha Kartini untuk bertemu dengan orangorang Belanda mengangumi karyanya.Dalam satu scene menunjukkan ketika Kartini dan kedua adik perempuannya pertama kali diundang dalam sebuah acara di Semarang yang dihadiri oleh para petinggi Belanda, R.M Slamet sempat mencoba untuk mendekati seorang Resident Belanda di Semarang bernama Pieter Sijthoff. Namun, Pieter lebih tertarik kepada Kartini.Sijthoff sangat mengagumi karya Kartini dan ingin memamerkannya di Den Haag Belanda sehubungan dengan penobatan Ratu Wihelmina. "saya sangat membutuhkan Kartini, dan sebagai gantinya saya akan memenuhi kebutuhan masa depan R.M Slamet dan Sosrobusono". Kedua kakak laki-laki Kartini yang merupakan keturunan bangsawan, digambarkan tidak memiliki kuasa sesungguhnya, dan nasib mereka ditentukan oleh pemerintahan kolonial pada masa itu.

Raden Mas Slamet dan Pangeran Adipati Sosrobusono juga ditampilkan membuat jarak dengan ibu mereka.Mereka lebih memilih untuk memanggil ibu mereka dengan sebutan $\mathrm{Yu}$ (pembantu). Seperti yang jelaskan oleh Gilligan dalam Nugroho (2017) bahwa laki-laki sejak terlahir dari kandungan ibunya, secara perlahan ia belajar bagaimana menjadi laki-laki yang kemudian membedakan dirinya dari sosok ibunya. Perkembangan moral laki-laki lebih menekankan pada prinsip pemisahan.Hal ini menandakan laki-laki berusaha mengambil jarak dari lingkungannya.Hal inilah yang kemudian 
membuat laki-laki dapat membangun dan menguatkan eksistensinya sebagai laki-laki.lakilaki berperan untuk menentukan hierarki dalam sebuah hubungan dan juga menjunjung tinggi aturan sebagai pedoman dalam berinteraksi dengan orang lain. Dalam konteks ini adalah bagaimana seharusnya menjadi seorang laki-laki bangsawan, sehingga kedua putra M.A Ngasirah tersebut lebih memilih untuk membuat jarak dirinya dari ibunya sendiri yang berasal dari kalangan jelata.

\section{Kesimpulan}

Film merupakan salah satu media yang sering digunakan untuk menghadirkan pengetahuan termasuk sejarah.Hanung Bramantyo berusaha menampilkan bagaimana kehidupan perempuan Indonesia dahulu yang masih sangat sarat akan tradisi yang kental akan budaya patriarki. Patriarki disebut-sebut banyak membelenggu kaum perempuan dan memberikan kebebasan pada kaum lakilaki.Namun, dalam tataran tertentu laki-laki juga terbelenggu oleh perannya sebagai seorang lakilaki terutaman bangsawan. Dalam film ini, tergambar bahwa laki-laki yang terpelajar seperti hal nya R.M Sosrokartono telah tercerahkan sehingga terbebas dari tradisi yang membelenggu laki-laki bangsawan lainnya. Bahkan ia yang pertama kali membukakan akses bagi Kartini untuk meraih kemerdekaan dalam berpikir. Namun disisi lain juga tergabarkan laki-laki yang masih memegang teguh tradisinya sebagai laki-laki bangsawan, justru menjadi lebih menderita. Dia tidak pernah benar-benar memilih. Seperti halnya R.M Adipati Ario Sosroningrat, ayah kartini yang digambarkan menderita dan tertekan hingga jatuh sakit, dan juga kedua kakak laki-laki Kartini yaitu R.M Slamet Sosroningrat dan P.A. Sosrobusono, yang harus menjauhkan dirinya dari ibu kandungnya dan juga diabaikan oleh pemerintah kolonial karena mereka menganggap lebih membutuhkan Kartini. Makadari itu dapat disimpulkan bahwa, patriarki bukan hanya membelenggu kaum perempuan, tapi juga lakilaki atas tuntutan perannya yang berat untuk menjadi laki-laki.

\section{Daftar pustaka}

Arivia, Gadis. 2003. "Filsafat Berperspektif Feminis". Jakarta : Yayasan Jurnal Perempuan.

Beauvoir, Simone de. (1989). "The Second Sex, book one: Facts and Myths." Diterjemahkan oleh Toni B. Ferianto. Yogyakarta.Narasi.

Connell, R.W dan Messerschmidt, James.W. 2005. "Hegemonic Masculinity", Cambridge: Polity Press.

Dayanti, L. D. 2011. Wacana Kekerasan dan Resistensi Perempuan dalam Film Karya Sutradara Perempuan.Kawistara, 1(2), 103-212

Demartoto, Argyo. 2010. Konsep Maskulinitas Dari Jaman Ke Jaman Dan Citranya 
Dalam Media.Diakses tanggal 14 Januari 2019 dari

http://argyo.staff.uns.ac.id/files/2010/08/

maskulinitas-ind1.pdf.

Hasan, Nur. 2012. "Corak Budaya Birokrasi pada Masa Kerajaan, Kolonial Belanda, hingga di Era Desentralisasi dalam Pelayanan Publik". Jurnal Hukum. Vol. XXVII. No 2. Pp: 1073-1087.

McQuail, Denis. 2012. Teori Komunikasi Massa. Jakarta : Salemba Humanika.

Nugroho, Hastanti Widi. 2017. "Politik Perempuan Hannah Arendt dalam Perspektif Filsafat". Jurnal Perempuan. Vol. 22 No.1. pp 81-104.
Rahayu, Angger Wiji. 2012. "Mitos, Data, dan Fakta Perempuan Pemimpin”. Jurnal Perempuan. Vol. 17. No. 4. Pp. 57-71.

Sobur, Alex. 2009. Analisis Teks Media. Bandung : PT Remaja Rosda.

Syulhajji. 2017. Representasi Maskulinitas dalam Film Talak 3.eJournal Ilmu Komunikasi, 5 (2), 1-11.

Toer, Pamoediya A. 2015.Panggil Aku Kartini Saja, (cetakan 11). Jakarta Timur: LENTERA DIPANTARA.

Zastrow, Charles. 2000. Introduction to Social Work and Social Welfare. United States : Brooks Cole. 